\title{
Spinach Effects (Amaranthus hybridus) on Spatial Memory
}

\author{
Intan Leonita ${ }^{1}$, Novi Vicahyani Utami ${ }^{2}$, Yusuf Wibisono ${ }^{3}$ \\ ${ }^{1}$ Faculty of Medicine, Universitas Padjadjaran, ${ }^{2}$ Department of Pharmacology and Therapy, \\ Faculty of Medicine, Universitas Padjadjaran, ${ }^{3}$ Department of Neurology, Faculty of Medicine, \\ Universitas Padjadjaran/Dr. Hasan Sadikin Hospital, Bandung, Indonesia
}

\begin{abstract}
Background: Spatial memory reduction in elderly is predicted to increase up to twice every 20 years. Spinach (Amaranthus hybridus) is widely consumed by Indonesian people and is believed to prevent declined spatial memory function. The aim of this study was to determine the effects of spinach on spatial memory in wistar rat induced by diazepam

Methods: An experimental study was conducted during the period of October to November 2012 in Pharmacology and Therapy Laboratory, Faculty of Medicine, Universitas Padjadjaran. Twenty five wistar rats were divided into 5 groups; two groups as controls, and 3 groups were given 100, 200, and 400mg/kg BW ethanolic extract of spinach (EESL), respectively. On day 7, group 3, 4, and 5 were given $1 \mathrm{mg} / \mathrm{kg} \mathrm{BW}$ diazepam injection. Morris water maze tests and calculations of escape latency time (ELT) were performed on day 7 and 8. Data were analyzed using analysis of variance (ANOVA) and least significance difference (LSD) test.

Results: On day 7, group 2 experienced acceleration in ELT compared to group 4 and group 5. On day 8, group 2 experienced acceleration in ELT compared to group 3 and group 4. There was no significant increase in spatial memory in group 5 (EESL $400 \mathrm{mg} / \mathrm{kg} \mathrm{BW}$ ) that due to the use of higher dosage does not always show better results.

Conclusions: EESL can prevent impairment of spatial memory with an effective dose of $200 \mathrm{mg} / \mathrm{kg}$ BW.
\end{abstract}

Keywords: Amaranthus hybridus, diazepam, spatial memory, spinach

\section{Introduction}

Prevalence of spatial memory dysfunction was predicted to increase at the age of $60 .^{1}$ The memory dysfunction in elderly is mostly manifested as Alzheimer's disease. Alzheimer's disease is a progressive disorder of memory function so that the patient becomes difficult to perform daily routine and has a behavioral change. ${ }^{2}$ World Health Organization (WHO) predicted that Alzheimer's cases will be double every 20 years, so in 2030 it can reach 65.7 million and reach 115.4 million people in $2050 .^{3}$

Nowadays, the treatment of spatial memory dysfunction is only symptomatic. ${ }^{4}$ Based on that, prevention is essential. The prevention can be implemented by regular exercise, active mental stimulation, good sleep quality, stress management, active social life and consumption of healthy foods. ${ }^{5}$ The consumption of foods that is rich of antioxidants such as strawberry, blueberry, and spinach can inhibit the neurodegenerative process. $^{6}$

Spinach (Amaranthus hybridus) is often consumed by Indonesian people because it is believed to have many benefits. Many studies have shown that spinach has a neuroprotective effect. However, there is no studies that have specifically observed at the effect of ethanolic extract of spinach (Amaranthus hybridus) in maintaining spatial memory function.

Diazepam is a Benzodiazepine with anticonvulsant, anxiolytic, sedative, muscle relaxant, and amnesic properties and a long duration of action. Its actions are mediated by enhancement of GAMMA-AMINOBUTYRIC ACID activity. It is used in the treatment of severe anxiety disorders, as a hypnotic in the shortterm management of insomnia, as a sedative and premedicant, as an anticonvulsant, and in the management of alcohol withdrawal syndrome (From Martindale, The Extra Pharmacopoeia, 30th ed, p589)..$^{7}$ Like other benzodiazepines, diazepam can impair shortterm memory and learn a new information as

Correspondence: Intan Leonita, Faculty of Medicine, Universitas Padjadjaran, Jalan Raya Bandung-Sumedang Km.21, Jatinangor, Sumedang, Indonesia, Phone: +62 8127059491 Email: intan_leonita@yahoo.com 
well as cause anterograde amnesia. ${ }^{8}$

The aim of this study is to determine the effect and effective dose of ethanolic extract of spinach (Amaranthus hybridus) in preventing spatial memory reduction (by accelerating escape latency time) in white wistar rat induced by diazepam.

\section{Methods}

This was an experimental study conducted during the period of October to November 2012 in Pharmacology and Therapy Laboratory, Faculty of Medicine, Universitas Padjadjaran, Bandung, Indonesia. Twenty five wistar rats (200-300 grams, 12-15 week sold, healthy and active) were used in this study with the following procedures: 1) The rats were adaptated for 7 days before treatment (placed in a closed container by wires hole, given appropriate light, standard pellet and water ad libitum) 2) Spinach (Amaranthus hybridus) used in this study was identified in the Laboratory of Plant Taxonomy Department of Biological Science Universitas Padjadjaran. Three kg of spinach was heated in the oven into dried simplicia. After that, the maceration was processed by inserting dried simplicia into the macerator and then blended it by $95 \%$ ethanol for $3 \times 24$ hours. The obtained aqueous extract was filtered into a pulp reservoir until the aqueous extract become almost colorless. The whole aqueous extracts were concentrated by rotating evaporator to get extract concentrated. Ethanolic extract of spinach (EESL) was diluted in $1 \mathrm{~mL}$ of $1 \%$ CMC3. After adaptation, rats were divided into 5 groups. Group 1 (negative control) and group 2 (positive control) were given food, water, and $1 \mathrm{~mL}$ of CMC (Carboxymethylcellulose) $1 \%$. Group 3, 4, and 5 were given food, water, and treated with ethanolic extract of spinach (each with the dosage 100, 200, and 400mg/ $\mathrm{kg}$ BW). All groups were treated for the next 7 consecutive days 4 ). On day 7 , group 2, 3, 4 and 5 were injected by $1 \mathrm{mg} / \mathrm{kg} / \mathrm{BW}$ diazepam after 90 minutes of the last treatment. Subsequently, groups 2, 3, 4, 5 underwent Morris water maze training session after 40 minutes of diazepam injection. Group 1 which did not receive diazepam injection, underwent the Morris water maze training session after 90 minutes of the last treatment. On day 8, all groups underwent Morris water maze for the second time. The length of ELT was obtained either day 7 or 8 from the Morris water maze test. 5) The escape latency time (ELT) was the time taken in seconds by the rats to swim from starting point to the hidden platform. Maximal time to explore the platform was 2 minutes or 120 seconds. Rats were allowed to explore the platform for additional 20 seconds. The ELT recorded on the first day was considered as a training session. Retention of this learned-task (memory) was examined in 24 hours after the first day trial (eighth day, 24 hours after the last dose). Significant reduction in ELT value of retention indicated improvement in memory.

The results of the study were expressed as mean \pm standard error of mean (SEM) and were analyzed using analysis of variance (ANOVA) followed by post hoc least significance difference (LSD). The $p$-values $<0.05$ were considered as statistically significant.

\section{Results}

On day 7 , the treatment group given with

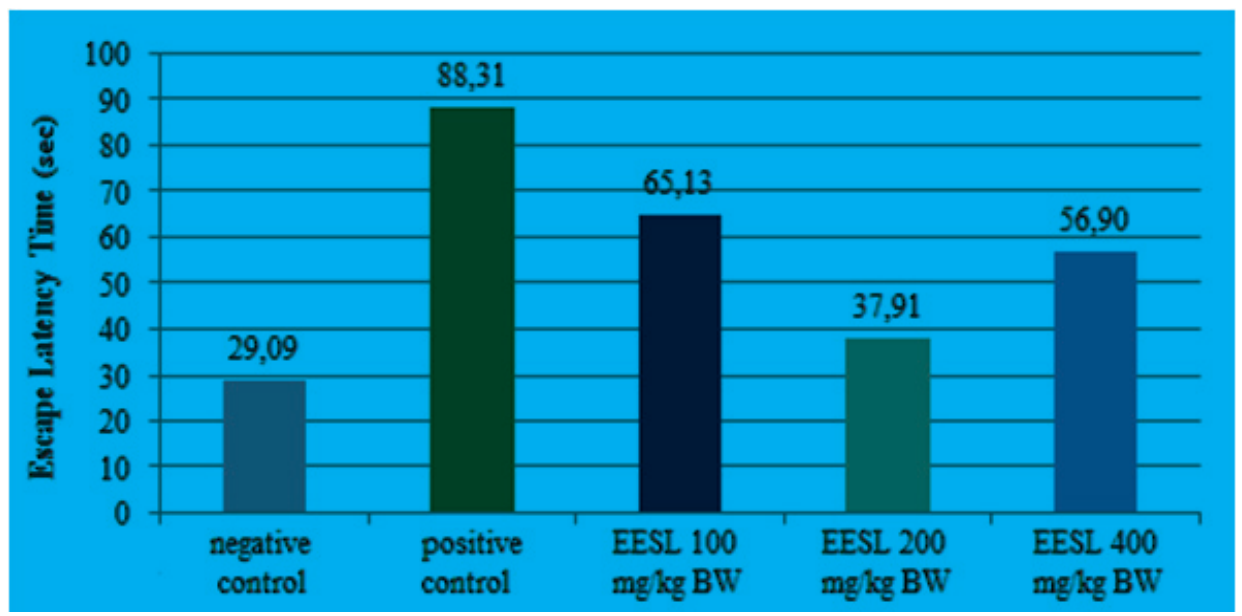

Figure 1 Graphic of ELT on Day7 
Table 1 ANOVA Test of ELT Comparison (seconds) after Induction of Diazepam in Group 2, 3,4 , and 5 (Day 7)

\begin{tabular}{|c|c|c|c|c|}
\hline Group & $\begin{array}{l}\text { Mean (Standard } \\
\text { Deviation) of ELT } \\
\text { (seconds) }\end{array}$ & $\begin{array}{c}\text { Normality Test } \\
p \text {-value }\end{array}$ & $\begin{array}{c}\text { Homogenity Test } \\
p \text {-value }\end{array}$ & $\begin{array}{c}\text { ANOVA Test } p- \\
\text { value }\end{array}$ \\
\hline 2 & $88.31(24.31)$ & 0.835 & \multirow{4}{*}{0.197} & \multirow{4}{*}{0.001} \\
\hline 3 & $65.13(25.77)$ & 0.524 & & \\
\hline 4 & 37.91 (15.51) & 0.557 & & \\
\hline 5 & $56.90(22.34)$ & 0.623 & & \\
\hline
\end{tabular}

Description:

Group 1: Rats were given standard food (pellet) and distilled water

Group 2: Rats were given standard food (pellet) and distilled water and diazepam injection $1 \mathrm{mg} / \mathrm{kg} \mathrm{BW}$

Group 3: Rats were given EESL $100 \mathrm{mg} / \mathrm{kg}$ BW and diazepam injection $1 \mathrm{mg} / \mathrm{kg} \mathrm{BW}$

Group 4:Rats were given EESL $200 \mathrm{mg} / \mathrm{kg}$ BW and diazepam injection $1 \mathrm{mg} / \mathrm{kg}$ BW

Group 5:Rats were given EESL $400 \mathrm{mg} / \mathrm{kg} \mathrm{BW}$ and diazepam injection $1 \mathrm{mg} / \mathrm{kg} \mathrm{BW}$

ethanolic extract of spinach 100, 200, and $400 \mathrm{mg} / \mathrm{kg}$ BW showed a better ELT on learning process compared to group 2 (positive control) after injection of diazepam (Figure 1).

The $p$-value in normality test was $>0.05$ which indicated the normal data distribution. Homogenity test produced $p$-value 0.197 $(p>0.05)$ which indicated the normal data variance, so then performed ANOVA test. The ANOVA test showed a p-value 0.001 $(p<0.05)$ which indicated that there were ELT significantly between the four groups. The group that had the difference of ELT significantly with other groups can be identified by Post Hoc LSD test (Table 1).

The LSD test in group 2 with group 4 and in group 2 with group 5 produced each $p$-value $<0.05$. It showed that the ethanolic extract of spinach dose of $200 \mathrm{mg} / \mathrm{kg} \mathrm{BW}$ and $400 \mathrm{mg} / \mathrm{kg}$ BW had effects in the process of learning by accelerating ELT in rats induced by diazepam (Table 2).

On day 8, the treatment groups given ethanolic extract of spinach each 100,200, and $400 \mathrm{mg} / \mathrm{kg}$ BW showed a better ELT compared to group 2 (positive control). It showed increases on spatial memory in groups 3,4 , and 5 (Figure2).

The ANOVA test showed a $p$-value 0.044 $(p<0.05)$ which indicated that there were differences of ELT significantly among the four groups. The group that had the difference of ELT significantly with other groups can be identified by Post Hoc LSD test (Table 3).

The LSD test in group 2 with group 3 and in group 2 with group 4 produced each $p$-value $<0.05$. It showed that the ethanolic extract of spinach dose of $100 \mathrm{mg} / \mathrm{kg}$ BW and $200 \mathrm{mg} / \mathrm{kg} \mathrm{BW}$ had an effect on spatial memory by accelerating ELT in rats induced by diazepam.

\section{Discussion}

The results of the study on day 7 and 8 showed that the dosage of EESL $200 \mathrm{mg} / \mathrm{kg} \mathrm{BW}$ (group 4) has a better result compared to other groups. These results indicate that the ethanolic extract of spinach (Amaranthus hybridus)

Table 2 LSD Test of ELT Comparison (seconds) in Rats Induced by Diazepam between Positive Control Group and Group Given Ethanolic Extract of Spinach (Day 7)

\begin{tabular}{ccc}
\hline & LSD test $\boldsymbol{p}$-value & Interpretation \\
\hline Group 2 \& 3 & 0.087 & Not Significant \\
Group 2 \& 4 & 0.001 & Significant \\
Group 2 \& 5 & 0.024 & Significant \\
Group 3 \& 4 & 0.047 & Significant \\
Group 3 \& 5 & 0.529 & Not Significant \\
Group 4 \& 5 & 0.155 & Not Significant \\
\hline
\end{tabular}




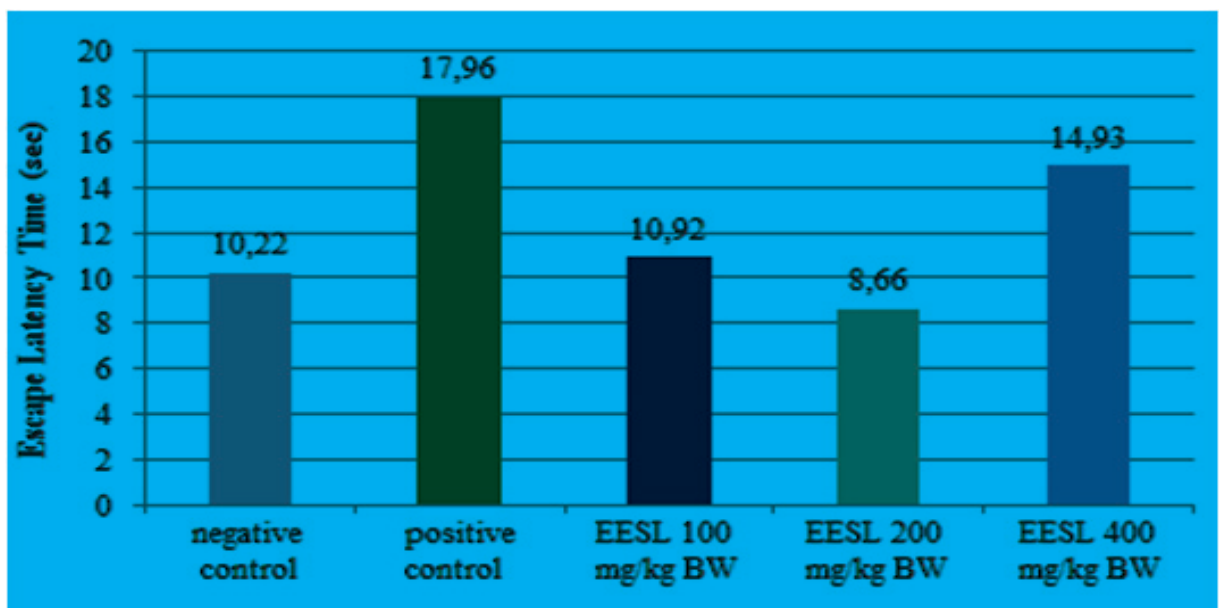

Figure 2 Graphic of ELT on Day 8

dosage of $200 \mathrm{mg} / \mathrm{kg}$ BW has the effect in preventing impairment of learning process and spatial memory by accelerating escape latency time in rats induced by diazepam.

The results showed that the ethanolic extract of spinach (Amaranthus hybridus) has the effect in preventing the decline in spatial memory by accelerating escape latency time in rats induced by diazepam, presumably because it owns compound of spinach namely folicacid, L-tyrosine, flavonoids, polyphenols, and beta-carotene. ${ }^{9,10}$

Kruman $^{11}$ stated that folate has a 5-methyltetrahydrofolate compound which provides methyl group to convert homocysteine into methionine, assisted by Lmethionine synthase enzyme. Homocysteine is a toxic and it can trigger apoptosis of brain cells due to DNA damage. ${ }^{12}$

L-tyrosine compound plays a role in reducing lipid peroxidation and DNA fragmentation thus providing neuroprotective effects. ${ }^{13}$ Tyrosine provides neuroprotective effect to acute stress by preventing the depletion of neurotransmitters in neurons. ${ }^{14}$

Flavonoids can stop oxidative reactions inducing neuronal damage by inhibiting the activation of caspase- 3 as its role as an anti-apoptosis. ${ }^{15}$ Flavonoids synthesize acetylcholine and factors such as brainderived neurotrophic factor (BDNF) and nerve growth factor (NGF) in the hippocampus and frontal cortex associated with spatial working memory improvement. ${ }^{15}$ Flavonols epicathec combining physical activity can increase the retention of rats' spatial memory with a mechanism involving angiogenesis in the hippocampus and increased regulation of genes associated with the learning process in the hippocampus. ${ }^{16}$

Interaction of polyphenols with protein kinases and lipid kinases can activate the extracellular signal-regulated kinase (ERK1/2) signaling pathway and protein kinase B/Akt, leading to activation of cAMP response element-binding (CREB) protein, a transcription factor that plays a role in increasing the number of neurotrophin expressions to improve memory and cognitive function. ${ }^{16}$

Another study conducted by Grodstein ${ }^{17}$ proved that beta-carotene functions as an antioxidant that can scavenge free radicals in lipidoxidation nerve cells and produce

Table 3 ANOVA Test of ELT Comparison (seconds) on Spatial Memory in Group 2, 3, 4, and 5 (Day 8)

\begin{tabular}{ccccc}
\hline Group & $\begin{array}{c}\text { Mean (Standard } \\
\text { Deviation) of ELT } \\
\text { (seconds) }\end{array}$ & $\begin{array}{c}\text { Normality Test } \\
\boldsymbol{p} \text {-value }\end{array}$ & $\begin{array}{c}\text { Homogenity Test } \\
\boldsymbol{p} \text {-value }\end{array}$ & $\begin{array}{c}\text { ANOVA Test } \boldsymbol{p} \text { - } \\
\text { value }\end{array}$ \\
\hline 2 & $17.96(6.66)$ & 0.354 & & \\
3 & $10.92(4.02)$ & 0.610 & 0.530 & 0.044 \\
4 & $8.66(3.04)$ & 0.954 & & \\
5 & $14.93(6.06)$ & 0.442 & & \\
\hline
\end{tabular}


Table 4 LSD Test of ELT Comparison of (seconds) between Positive Control Group and the Group Given Ethanolic Extract of Spinach (Day 8)

\begin{tabular}{ccc}
\hline & LSD test p-value & Interpretation \\
\hline Group 2 \& 3 & 0.035 & Significant \\
Group 2 \& 4 & 0.007 & Significant \\
Group 2 \& 5 & 0.344 & Not Significant \\
Group 3 \& 4 & 0.476 & Not Significant \\
Group 3 \& 5 & 0.213 & Not Significant \\
Group 4 \& 5 & 0.058 & Not Significant \\
\hline
\end{tabular}

neuroprotective effects.

The treatment group 5 (EESL $400 \mathrm{mg} / \mathrm{kg}$ BW) showed a significant increase in spatial memory, but not significant compared to the other treatment groups, due to the use of higher dosage of vegetables does not always show better results than smaller dosage. Smaller dosage can provide more effective results. Possibility that occurs is the biological maximum tolerated dose in the rats. ${ }^{18}$ Smaller dosages are more effective than larger dosages and how consistency of target plasma level forethanolic extract of spinach based on rat models. ${ }^{19}$ Effective doses at lower dosage showed no oxicity effects that occur at these levels. Chemical compounds given in small dosage can provide an effective and useful to a tissue or organ. In contrast, inexcessive dosages can give harmful effects on the body. ${ }^{20}$

The study was inhibited by lack of comparison between result on day 7 and day 8. This study concludes that there is an effect of ethanolic extracts of spinach (Amaranthus hybridus) in preventing impairment on spatial memory by accelerating ELT in white wistar rats induced by diazepam. The effective dosage of ethanolic extracts of spinach (Amaranthus hybridus) in preventing impairment on spatial memory by accelerating ELT in white wistar rats induced by diazepam is $200 \mathrm{mg} / \mathrm{kg} \mathrm{BW}$. Advice given for further study should be done to determine the dominan compound of spinach in preventing spatial memory.

\section{References}

1. European Commission. Alzheimer disease and other dementias. Brussels; 2010 [Cited 1 December 2012]; Available from: http://ec.europa.eu/health/major chronic_diseases/diseases/alzheimer/ index_en.htm.

2. Williams JM, Barnhofer T, Crane C, Herman D, Raes F, Watkins E, et al. Autobiographical memory specificity and emotional disorder. Psychol Bull. 2007;133(1):12248.

3. World Health Organization.Fact sheet No 362: dementia.2012 [Cited 10 May 2012]; Available at:http://www.who.int/ mediacentre/factsheets/fs362/en/index. html.

4. Wortmann M. Role of the global Movement. In: Alzheimers Disease International. Proceeding of The Fight Against Alzheimer's Disease and Related Disorders Conference; 2008 October 3031; Paris. Paris:Bibliotheque Nationale de France; 2008 [Cited 24 September 2012]; Available at: http://www.plan-alzheimer. gouv.fr/IMG/pdf/Alzheimer_conference_ EN_081030.pdf.

5. Smith M, Robinson L, Segal J. Alzheimer's and dementia prevention: how to reduce your risk and protect your brain as you age.Santa Monica: Helpguard.org International;2012 [Cited 3 December 2012]; Available at: http://www. helpguide.org/articles/alzheimersdementia/alzheimers-and-dementiaprevention.htm.

6. Joseph JA, Shukitt-Hale B, Casadesus G. Reversing the deleterious effects of aging on neuronal communication and behavior: beneficial properties of fruit polyphenolic compounds. Am J Clin Nutr. 2005;81(1 Suppl):313S-6S.

7. National Center for Biotechnology Information. PubChem Compound Database; CID=3016 (Diazepam). 2012. [Cited 3 December 2012]; Available athttp://pubchem.ncbi.nlm.nih.gov/co mpound /3016\#section=InformationSources.

8. Yudofsky SC, Hales RE. The American Psychiatric Publishing Textbook of Neuropsychiatry and Behavioral Neurosciences.5ed. Arlington: American 
Psychiatric Publishing, Inc. 2008. p. 583584.

9. Subhash GP, Virbhadrappa SR, Vasant OK. Spinacia Oleracea Linn: apharmacognictic and pharmacological overview. IJRAP. 2010;1(1):78-84.

10. Gómez-Pinilla F. Brain foods: the effects of nutrients on brain function. Nat Rev Neurosci. 2008;9(7):568-78

11. Kruman II, Kumaravel TS, Lohani A, Pedersen WA, Cutler RG, Kruman Y, et al. Folic acid deficiency and homocysteine impair DNA repair in hippocampal neurons and sensitize them to amyloid toxicity in experimental models of Alzheimer's disease. J Neurosci. 2002;22(5):1752-62.

12. Walker JG, Batterham PJ, Mackinnon AJ, Jorm AF, Fenech M, Kljakovic M, et al. Oral folicacid and vitamin B-12 supplementation to preventcognitive decline in communitydwelling older adults with depressive symptoms - the beyond ageing project: a randomized controlled trial. Am J Clin Nutr. 2012;95:194-203.

13. Yao L-Y, Lin Q, Niu Y-Y, Deng K-M, Zhang $\mathrm{J}-\mathrm{H}, \mathrm{Lu}$ Y. Synthesis of lipoamino acids and their activity against cerebral ischemic injury. Molecules. 2009;14(10):4051-64

14. Tumilty L, Davison G, Beckmann M, Thatcher R. Oral tyrosine supplementation improves exercise capacity in the heat. Eur J Appl Physiol. 2011;111(12):2941-50.

15. Vauzour D, Vafeiadou K, RodriguezMateos A, Rendeiro C, Spencer JP. The neuroprotective potential of flavonoids: a multiplicity of effects. Genes Nutr. 2008;3(3-4):115-26.

16. Kovacsova M, Barta A, Parohova J,
Vrankova S, Pechanova O. Neuroprotective mechanisms of natural polyphenolic compounds. Act Nerv Super Rediviva. 2010;52(3):181-6.

17. Grodstein F, Kang JH, Glynn RJ, Cook NR, Gaziano JM. A randomized trial of beta carotene supplementation and cognitive function in men: the Physicians' Health Study II. Arch Intern Med. 2007;167(20):2184-90.

18. Cone M. Low doses, big effects: Scientists seek 'fundamental changes' in testing, regulation of hormone-like chemicals. Environmental Health Services; 2012 [Cited 1 December 2012]; Available at: http://www.environmentalhealthnews. org/ehs/news/2012/low-doses-bigeffects.

19. U.S Department of Health and Human Services Food and Drug Administration, Center for Drug Evaluation and Research. Guidance for industry, investigators, and reviewers: exploratory IND studies. Rockville: Center for Drug Evaluation and Research Food and Drug Administration.; 2006 [Cited 1 December 2012]; Availableat: http://www.fda.gov/downloads/Drugs/ anceComplianceRegulatoryInformation/ Guidances/ucm078933.pdf.

20. The Society of Toxicology. Animals in research: the importance of animals in the science of toxicology. Reston:The Society of Toxicology; 2006 [Cited 1 December 2012]; Available at: http:// www.toxicology.org/ai/air/AIR_Final.pdf. danceComplianceRegulatoryInformation/ Guidances/ucm078933.pdf. 